\title{
NOTE
}

\section{Regulation of estuarine primary production by watershed rainfall and river flow}

\author{
Michael A. Mallin*, Hans W. Paerl, Joseph Rudek**, Paul W. Bates*** \\ University of North Carolina, Institute of Marine Sciences, Morehead City, North Carolina 28557, USA
}

\begin{abstract}
Enhanced phytoplankton production and algal blooms, symptoms of eutrophication, are frequently caused by elevated nutrient loading, usually as nitrogen, to coastal waters. This nitrogen is derived primarily from anthropogenic sources (urban, industrial, and agricultural) but is delivered to coastal waters through meteorological and hydrological means. We utilized a 4 yr monthly data set to investigate the effect of these upstream physical forces upon primary productivity of the Neuse River Estuary (North Carolina, USA), a large temperate coastal plain estuary. Our results indicate that the magnitude of estuarine primary production and the periodicity of algal blooms can be directly related to variations in upper watershed rainfall and its subsequent regulation of downstream river flow. Future changes in precipitation patterns for coastal regions may thus lead to substantial alterations in coastal primary productivity rates and patterns.
\end{abstract}

Biological productivity in estuarine waters is influenced by a host of factors including latitude, season, irradiance, temperature, flow, nutrient loading and recycling, grazing, and watershed geomorphology and development (Mann 1982, Nixon 1986, Day et al. 1989). Upstream river flow has been recognized as an important influence on the primary productivity, salinity, nutrient loading, light attenuation, dissolved oxygen, and stratification of estuarine waters (Cooper \& Copeland 1973, Jaworski 1981, Sellner 1987, Randall \& Day 1987, Malone et al. 1988, Christian et al. 1991, Jordan et al. 1991, Rudek et al. 1991, Gallegos et al. 1992). Factors controlling river flow should, therefore, be expected to affect estuarine primary productivity.

Present addresses:

- Department of Biological Sciences, University of North Carolina at Wilmington, Wilmington, North Carolina 28403, USA

- USGS MS 469, 345 Middlefield Rd, Menlo Park, California 94025, USA

-.Department of Horticulture, 1575 Linden Dr., University of Wisconsin, Madison, Wisconsin 53706, USA
The Neuse River Estuary, North Carolina, USA, typifies coastal plain estuaries with its large drainage basin $\left(16000 \mathrm{~km}^{2}\right)$, relatively shallow water, and elevated nutrient loading from urban, industrial, and agricultural sources (Stanley 1988, Christian et al. 1991). Bioassays have indicated that primary productivity is predominantly nitrogen-limited in this system (Rudek et al. 1991). The phytoplankton community is dominated by centric diatoms, dinoflagellates, and cryptomonads, with community structure influenced by salinity; increased freshwater inputs favor cryptomonads, whereas diatoms tend to dominate under more saline conditions, and dinoflagellates are usually subdominant except for periodic blooms (Mallin et al. 1991). Previous research indicated that during 1988-1989 primary productivity was strongly correlated with surface nitrate concentrations and negatively correlated with salinity (Mallin et al. 1991). Also, periods of increased river flow were associated with increases in nitrate and decreases in salinity (Rudek et al. 1991). Based on this information, our objective in the present research was to examine how the interplay of physical and chemical variables affected estuarine primary productivity from an ecosystem perspective. Accordingly, we utilized a long-term data set to investigate the extent to which river flow and its primary driving force, watershed rainfall, influenced the primary productivity of this large temperate estuary.

Materials and methods. We sampled for phytoplankton productivity, taxa composition and abundance, chlorophyll $a$, nutrients, and physical factors at Channel Marker 6, a mesohaline station located about $10 \mathrm{~km}$ from the mouth of the estuary where it joins Pamlico Sound (Fig. 1). Samples were collected approximately monthly over a 4 yr period (1988 to 1992). Primary productivity was assessed by the ${ }^{14} \mathrm{C}$ 


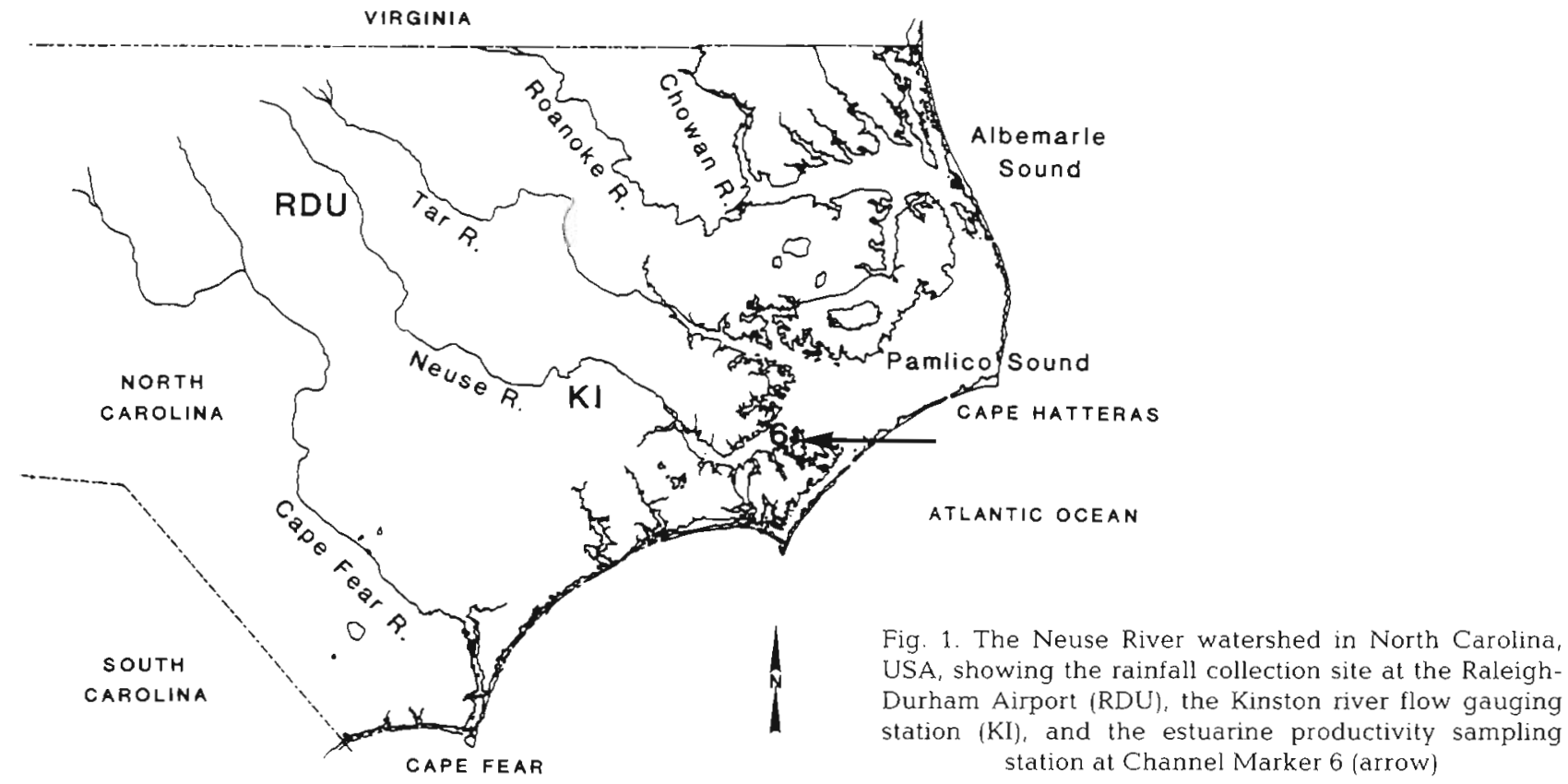

uptake method, modified to account for variable irradiance caused by water-column mixing (Mallin et al. 1991, Mallin \& Paerl 1992). Phytoplankton cell counts were performed using the procedure detailed in Mallin et al. (1991), following a membrane filtration procedure (Crumpton 1987). Chlorophyll a was assessed spectrophotometrically using the trichromatic method (Strickland \& Parsons 1972), and nitrate concentration was determined using the cadmium reduction technique (Strickland \& Parsons 1972). River flow data were collected at a gauging station located at Kinston, North Carolina, $120 \mathrm{~km}$ upstream of the sampling site. Daily rainfall data were obtained from the Raleigh-Durham Airport (RDU), $145 \mathrm{~km}$ upstream of the Kinston gauging station (Fig. 1). The rain data was collected from RDU for 2 reasons: it is located in the headwaters area of the Neuse River, and complete rainfall records are available.

We utilized correlation analyses to investigate the relationships between primary productivity and associated chemical and physical variables. Because we used multiple correlations, Bonferroni's correction was applied to control for the group-wide type-I error rate by adjusting the individual $\alpha$ values downward (Rice 1989).

Results. On a broad temporal scale annual primary production varied considerably over the study period (Table 1). Years of elevated primary production and chlorophyll a appeared to be associated with years of increased nitrate and river flow and decreased salinity. Primary productivity generally increased during summer (Fig. 2), a common phenomenon in temperate estuaries often attributed to increased water temperature and light (Day et al. 1989). However, in addition to summer maxima, periodic productivity pulses and algal blooms occurred in winter, spring, and fall (Fig. 2). Winter blooms mainly consisted of the dinoflagellates Heterocapsa triquetra and Gymnodinium sp.; spring and fall blooms were often dominated by cryptomonads or the dinoflagellate Prorocentrum minimum. The timing of pulse blooms frequently coincided with episodic rainfall and runoff events (Fig. 2). River flow and estuarine nitrate concentrations did not display any regular seasonal patterns during the study.

Given the appreciable distance between the estuarine sampling site and and the river gauging station, we found that variable river flow velocities could best be accounted for by using the mean daily flow for the 2 wk period preceding each experiment as our flow variable. Our results showed that estuarine primary productivity and nitrate concentration were both significantly correlated with upstream river flow

Table 1. Annual primary production and related annual mean variables for the Neuse River Estuary, 1988 to 1991. Primary production is in $\mathrm{g} \mathrm{C} \mathrm{m}^{-2}$, chlorophyll a ( $\mathrm{chl}$ a) is in $\mathrm{mg} \mathrm{m}^{-3}$, salinity is in ppt, $\mathrm{NO}_{\mathrm{x}}$ is nitrate + nitrite in $\mu \mathrm{M} \mathrm{N}$, flow $\left(\mathrm{m}^{3} \mathrm{~s}^{-1}\right)$ is annual mean for the $14 \mathrm{~d}$ periods preceding the productivity measurements

\begin{tabular}{|cccccc|}
\hline Year & Primary prod & Chl a & Salinity & NOx & Flow \\
\hline 1988 & 204.0 & 10.3 & 15.4 & 0.17 & 1058 \\
1989 & 277.5 & 12.3 & 13.6 & 0.71 & 4677 \\
1990 & 320.0 & 16.9 & 13.8 & 0.24 & 2993 \\
1991 & 202.2 & 9.9 & 17.4 & 0.22 & 2141 \\
\hline
\end{tabular}




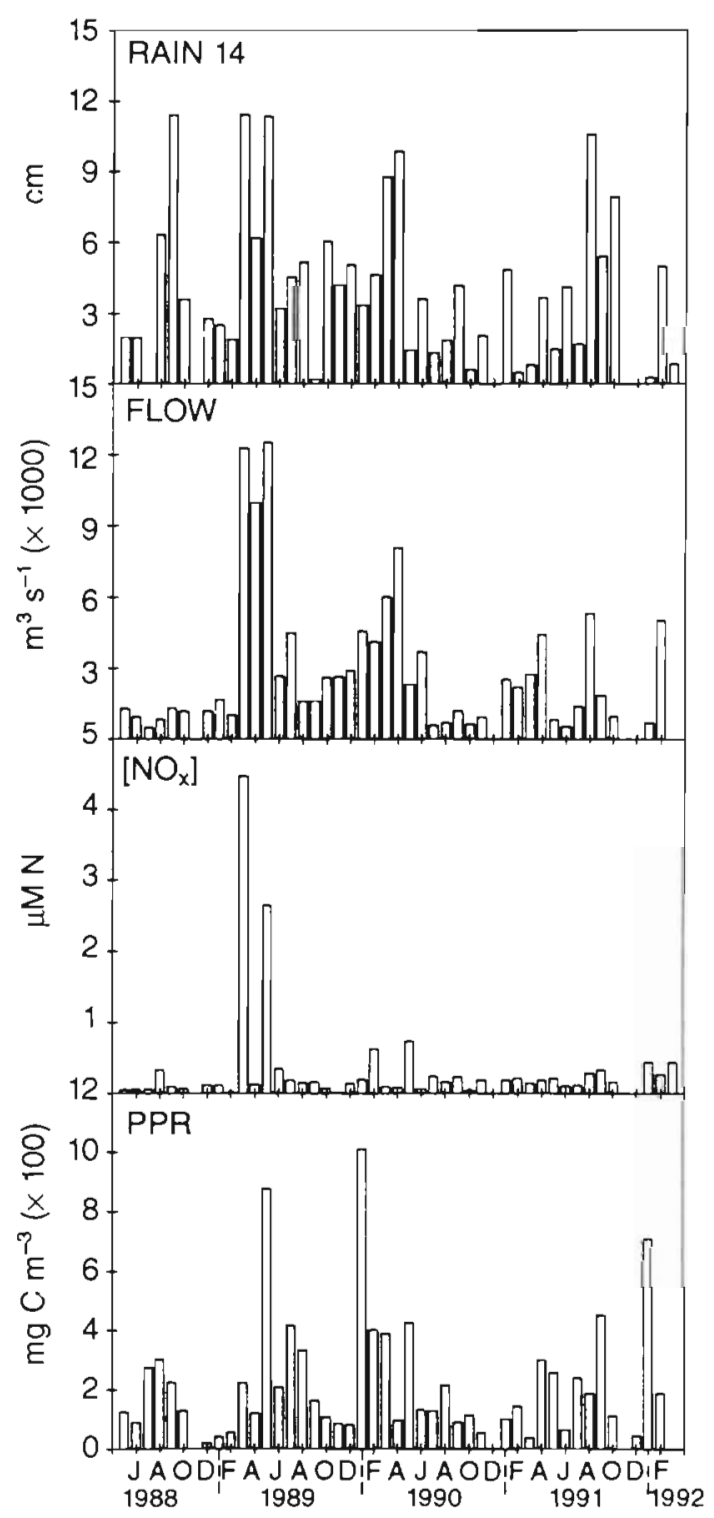

Fig. 2. Seasonal patterns of primary productivity (PPR) and related variables in the Neuse River Estuary, May 1988 to February $1992 . \mathrm{NO}_{x}$ is nitrate + nitrite in $\mu \mathrm{MN}$. Flow is mean daily flow at Kinston gauging station for $14 \mathrm{~d}$ period preceding productivity measurement. Rain 14 is total rainfall at RaleighDurham Airport for the period between 28 and $14 \mathrm{~d}$ preceding the productivity experiment. Lag times are removed from flow and rainfall variables, normalizing them to the corresponding estuarine $\mathrm{NO}_{\mathrm{x}}$ and productivity measurements

(Table 2). Simple linear regression analysis indicated that flow alone explained nearly $50 \%$ of the variation in nitrate concentration in the lower estuary during the 4 yr period $\left(\mathrm{r}^{2}=0.46, \mathrm{p}=0.0001\right)$.

Watershed rainfall, the major factor which ultimately controls river flow, substantially influenced estuarine primary productivity and associated variables. Total rainfall in the upper watershed (measured at RDU) for
Table 2. Correlation matrix of Neuse Estuary primary productivity and related variables, May 1988 to January 1992. Flow is mean daily flow at Kinston gauging station for $14 \mathrm{~d}$ period preceding the productivity measurement, Rain is total rainfall at RDU during the period between 28 and $14 \mathrm{~d}$ preceding the productivity measurement, $\mathrm{NO}_{\mathrm{x}}$ is estuarine nitrate + nitrite concentration. Upper values are correlation coefficient $(r)$, lower values are probability $(p) ; n=42$, adjusted $\alpha$ value $=0.01$

\begin{tabular}{|lcll|}
\hline & Productivity & Rain & $\mathrm{NO}_{x}$ \\
\hline Flow & 0.419 & 0.667 & 0.678 \\
& 0.006 & 0.0001 & 0.0001 \\
$\mathrm{NO}_{\mathrm{x}}$ & 0.290 & 0.464 & \\
& 0.063 & 0.002 & \\
\hline
\end{tabular}

the $28 \mathrm{~d}$ period preceding each experiment was correlated with estuarine primary productivity $(p=0.047)$ and nitrate concentration ( $p=0.025$ ); however, these relationships were not significant at the adjusted $\alpha$ value (0.01). Since the rainfall collection station was $145 \mathrm{~km}$ upstream of the Kinston flow gauging station, consideration of a lag period was necessary to more precisely define the relationship between watershed rainfall and downstream environmental parameters. Rainfall in the upper watershed during the $14 \mathrm{~d}$ preceding productivity measurements was not significantly correlated with downstream or estuarine variables. However, with inclusion of a $2 \mathrm{wk}$ lag period, total rainfall for the period 28 to $14 \mathrm{~d}$ before the productivity measurements was strongly correlated with flow at Kinston, and also highly correlated with nitrate concentrations at the estuarine sample site (Table 2). Thus, with consideration of a suitable lag period, the data indicate that rainfall in the upper watershed regulates flow in the lower river which, in turn, significantly influences nitrogen concentration and primary productivity in the lower estuary.

Discussion. Local rainfall events have been shown to significantly stimulate primary productivity when directly deposited in estuaries and coastal waters (Paerl 1985, Paerl et al. 1990, Willey \& Cahoon 1991). Because these events are scattered and episodic, the overall effect on coastal production is difficult to quantify. In this study, local rainfall parameters were not significantly correlated with monthly primary productivity. Upstream, the watershed serves as a catch basin that integrates episodic rainfall events, ultimately funneling them to the river. Elevated watershed rainfall causes natural and anthropogenically derived nitrogen to enter the rivers and estuaries through both overland and groundwater flow (Showers et al. 1990). Additionally, rainfall itself is a significant source of directly deposited, biologically available nitrogen species to watersheds, rivers, and estuaries (Likens et al. 1972, Paerl et al. 1990). Likewise, dry deposition of nitrogen can be significant (Duce 1986, Morris 1991) 
and this material may enter the river via overland flow during rainfall events as well. Runoff over the large area of the watershed concentrates and magnifies river nitrogen loading from these scattered atmospheric and terrestrial sources, thus forcing the significant estuarine productivity increases downstream.

Under normal flow conditions estuaries can act as filters, reducing water-column nutrient concentrations through biological activity as the water moves downstream (Jaworski 1981, Christian et al. 1991). During wet periods in the Neuse watershed the increased flow (and associated increase in nutrient loading) exceeds this nutrient filtering capability, leading to substantial nutrient enrichment in the lower estuary, and thus stimulating algal blooms (Mallin et al. 1991, Rudek et al. 1991). The contribution of these winter and spring pulse blooms to annual estuary production can be substantial. Largely in response to watershed rainfall variations, annual primary production levels in the Neuse River Estuary varied by as much as $37 \%$ during this study (Table 1).

Primary productivity in the Neuse River Estuary generally is nitrogen-limited (Rudek et al. 1991) and, therefore, the highly significant correlations between variations in the forces controlling delivery of nitrogen to the estuary and productivity pulses are reasonable. Hydrologically and morphologically the Neuse watershed is representative of other coastal rivers in North Carolina (Fig. 1), and possibly of those in other regions as well. Since many other temperate estuaries are wholly or partially nitrogen-limited (Thayer 1974, D'Elia et al. 1986, Howarth 1988, Graneli et al. 1990, Fisher et al. 1992), similar relationships between upstream rainfall and downstream primary productivity variations may be common. Lag times between upstream rainfall, flow, and estuarine biological responses will doubtless vary in other systems depending on distance and hydrology. It is important to examine the effects of rainfall and associated runoff pulses from a short time-scale perspective (days to months) as well as a long-term (annual) basis to clearly elucidate cause and effect mechanisms between upstream materials transport and downstream effects (Howarth et al. 1991, Gallegos et al. 1992).

These results have several implications for coastal research. For instance, timing and duration of sampling programs are critical when assessing anthropogenic nutrient impacts on estuaries. In the Neuse Estuary, sampling during dry years $(1988,1991)$ would have indicated a system of moderate productivity, whereas sampling during wet years $(1989,1990)$ would have indicated a eutrophic system (Nixon 1986, Day et al. 1989). Likewise, the effect of episodic rainfall and runoff events must be considered in mitigation efforts to reduce nutrient loading to coastal systems. Finally, while future global warming scenarios do include changes in the precipitation patterns of coastal regions, the direction and magnitudes suggested by present models are not in agreement (Smith 1990). If there is a significant increase in precipitation for regions bordering coastal areas, increases in river nitrogen loading and coastal eutrophication may be expected. If precipitation decreases, coastal primary production may also decline, leading to possible trophic implications, including reductions in fisheries productivity.

Acknowledgements. This research was supported by the Office of Sea Grant, NOAA, U.S. Dept. of Commerce (Grant No. NA86AA-D-SG046), University of North Carolina Sea Grant College (Project R/MER-10), the Aibemarle-Pamlico Estuarine Study (Grant No. EPA-CE 00470601), the USGS/North Carolina Water Resources Research Institute (Project No. 20157), and the Atlantic Estuarine Research Society (AERS). We thank J. M. Burkholder and R. W. Howarth for manuscript comments, G. A. Skilleter for statistical advice, O. Lewis and J. Purifoy of the RV 'Capricorn' for field assistance, and $\mathrm{H}$. Barnes for preparing the map. We also thank J. D. Bales and T K. Manning of the U.S. Geological Survey in Raleigh for flow data, and J. A. Enman of the State Climatology Office, NCSU, Raleigh, for rainfall data.

\section{LITERATURE CITED}

Christian, R. R., Boyer, J. N., Stanley, D. W. (1991). Multi-year distribution patterns of nutrients within the Neuse River Estuary, North Carolina. Mar. Ecol. Prog. Ser. 71: 259-274

Cooper, D. C., Copeland, B. J. (1973). Responses of continuous-series estuarine microecosystems to point-source input variation. Ecol. Monog. 43: 213-236

Crumpton, W. G. (1987). A simple and reliable method for making permanent mounts of phytoplankton for light and fluorescence microscopy. Limnol. Oceanogr. 32: $1154-1159$

Day, J. W., Hall, C. A. S., Kemp, W. M., Yanez-Arancibia, A. (1989). Estuarine ecology. John Wiley and Sons, New York

D'Elia, C. F., Sanders, J. G., Boynton, W. R. (1986). Nutrient enrichment studies in a coastal plain estuary: phytoplankton growth in large-scale, continuous cultures. Can. J. Fish. Aquat. Sci. 43: 397-406

Duce, R. A. (1986). The impact of atmospheric nitrogen, phosphorus, and iron species on marine biological productivity. In: Buat-Menard, P. (ed.) The role of air-sea exchange in geochemical cycling. D. Reidel Publishing, Berlin, p. $497-529$

Fisher, T R., Peele, E. R., Ammerman, J W. Harding, L. W. (1992). Nutrient limitation of phytoplankton in Chesapeake Bay. Mar. Ecol. Prog. Ser. 82: 51-63

Gallegos, C. L., Jordan, T. E., Correll, D. L. (1992). Event-scale response of phytoplankton to watershed inputs in a subestuary: timing, magnitude, and location of blooms. Limnol. Oceanogr. 37: 813-828

Graneli, E., Wallstrom, K., Larsson, U., Graneli, W., Elmgren, R. (1990). Nutrient limitation of primary production in the Baltic Sea area. Ambio 19: 142-151

Howarth, R. W. (1988). Nutrient limitation of net primary production in marine ecosystems. A. Rev. Ecol. Syst. 19: $89-110$ 
Howarth, R. W., Fruci, J. R., Sherman, D. (1991). Inputs of sediment and carbon to an estuarine ecosystem: influence of land use. Ecol. Appl 1: 27-39

Jaworski, N. A. (1981). Sources of nutrients and the scale of eutrophication problems in estuaries. In: Nielson, B. J., Cronin, L. E. (eds.) Estuaries and nutrients. Humana Press, Clifton, $\mathrm{NJ}$

Jordan, T E., Correll, D. L., Miklas, J., Weller, D. E. (1991). Long-term trends in estuarine nutrients and chlorophyll, and short-term effects of variation in watershed discharge. Mar. Ecol. Prog. Ser. 75: 121-132

Likens, G. E., Bormann, F. H., Johnson, N. M. (1972). Acid rain. Environment 14: 33-40

Mallin, M. A., Paerl, H. W. (1992) Effects of variable irradiance on phytoplankton productivity in shallow estuaries. Limnol. Oceanogr. 37: 54-62

Mallin, M. A., Paerl, H. W., Rudek, J. (1991). Seasonal phytoplankton composition, productivity and biomass in the Neuse River Estuary, North Carolina. Estuar. coast. Shelf Sci. 32: 609-623

Malone, $\Upsilon$ C., Crocker, L. H., Pike, S. E., Wendler, B. W. (1988). Influences of river flow in the dynamics of phytoplankton production in a partially stratified estuary. Mar. Ecol. Prog. Ser. 48: 235-249

Mann, K. H. (1982). Ecology of coastal waters; a systems approach. Univ. of California Press, Berkeley

Morris, J. T. (1991). Effects of nitrogen loading on wetland ecosystems with particular reference to atmospheric deposition. A. Rev. Ecol. Syst. 22: 257-279

Nixon, S. W. (1986). Nutrient dynamics and the productivty of marine coastal waters. In: Halwagy, R., Clayton, D., Behbehani, M. (eds.) Marine environment and pollution. The Alden Press, Oxford, p. 97-115

Paerl, H. W. (1985). Enhancement of marine primary production by nitrogen-enriched acid rain. Nature 316: 747-749

Paerl, H. W., Rudek, J., Mallin, M. A. (1990). Stimulation of phytoplankton production in coastal waters by natural

This note was presented by G. W. Thayer, Beaufort, N. Carolina, USA rainfall inputs: nutritional and trophic implications. Mar. Biol. 107: 247-254

Randall, J. M., Day, J. W. (1987). Effects of river discharge and vertical circulation on aquatic primary production in a turbid Louisiana (USA) estuary. Neth. J. Sea Res. 21: 231-242

Rice, W. R. (1989). Analyzing tables of statistical tests. Evolution 43: 223-225

Rudek, J., Paerl, H. W., Mallin, M. A., Bates, P. W. (1991). Seasonal and hydrological control of phytoplankton nutrient limitation in the lower Neuse River Estuary, North Carolina. Mar. Ecol. Prog. Ser. 75: 133-142

Sellner, K. G. (1987). Phytoplankton in Chesapeake Bay: role in carbon, oxygen and nutrient dynamics. In: Majumdar, S. K., Hall, L. W., Austin, H. M. (eds.) Contaminant problems and management of living Chesapeake Bay resources. Pennsylvania Academy of Science, Philadelphia

Showers, W. J., Eisenstein, D. M., Paerl, H. W., Rudek, J. (1990). Stable isotope tracers of nitrogen sources to the Neuse River, North Carolina. Water Resources Research Institute Rep. No. 253, Univ. of North Carolina, Raleigh

Smith, J. B. (1990). From global to regional climate change relative knowns and unknowns about global warming. Fisheries 15: 2-6

Stanley, D. W. (1988). Historical trends in nutrient loading to the Neuse River Estuary, North Carolina. In: Lyke, W. L. Hoban, T. J. (eds.) Proc. Symp. Coastal Water Resources. AWRA Technical Publ. Series TPS-88-1. American Water Resources Association, Bethesda, MD

Strickland, J. D. H., Parsons, T. R. (1972). A practical handbook of seawater analysis, 2nd edn. Bull. Fish. Res. Bd Can. 167: 1-310

Thayer, G. W. (1974). Identity and regulation of nutrients limiting phytoplankton production in the shallow estuaries near Beaufort, N.C. Oecologia 14: 75-92

Willey, J. D., Cahoon, L. B. (1991). Enhancement of chlorophyll a production in Gulf Stream surface seawater by rainfall nitrate. Mar. Chem. 34:63-75

Manuscript first received: August 20,1992

Revised version accepted: November 10, 1992 